\title{
Entreupreuneurship Strategy of Seller and Restaurant Owner
}

\author{
Thriwaty Arsal \\ Dosen Jurusan Sosiologi dan Antropologi \\ Fakultas Ilmu Sosial \\ Universitas Negeri Semarang \\ thriwatyarsal@gmail.com, sosant@mail.unnes.ac.id
}

\begin{abstract}
The existence of restaurant is important to recognize because this a kind of business which contributes in helping to solve the employment problem directly and indirectly, that kind of business is very important to help in developing the economy of the community. Objectives: 1 . To learn about how restaurant owners provide services, the quality, and develop relationships with customers. 2 . To learn about the continuance of restaurant business development with the subjects. Research method used is descriptive qualitative. The data collection was conducted through in-depth interview. The result shows that restaurants apply management for distribution of the works based on working days and holidays, the arrangement of working hours adjusted with the opening and closing time, dividing the role on who will work as the waiter/waitress and the cashier, the cook and the rest do the management for the salary together that is already adjusted with the minimum standards for the employees and the owner.
\end{abstract}

Keyword : Entreupreuneurship, Management, Restaurant, Strategy, Owner

\section{I. . INTRODUCTION}

Entrepreneurship would need an understanding on market and marketing, no exception for a food stall business. The existence of food stall is important to be recognized since it is included in type of people entrepreneurship that helps to solve direct and indirect employment problems. Direct employment gives productive jobs for owner and its employees; whereas, indirect employment will support other unrelated jobs such as trade in agricultural, livestock and fishery products for the surrounding farmers and traders in the market [1]

Understanding food staller entrepreneurship will be useful to determine measure and policy that support the development of one of types of people small business in accordance with its characteristics that consists of potentials, threats, strengths and weaknesses of the entrepreneurship. If related to the view on entrepreneurship, the existence of entrepreneurial society is an important part in the dynamicization of community economy. According $\mathrm{Mc}$ Clelland, a society or nation that wants to move forward would need to increase the emergence of entrepreneurial society since it is important for the dynamic of economy; therefore, understanding the entrepreneurial society will be needed.
Definitive conclusions have yet to be made about the criteria by which restaurant patrons assess service quality and how best restaurateurs can improve their service offerings. The study also offers some insights on the aspects of service which restaurant patrons consider most important [2]

\section{RESEARCH METHOD}

The study used a qualitative approach with case method. The data collection was conducted through in-depth interview technique toward the subjects of the research which were selected through snowball sampling, which was the restaurant owners and the consuments as the customers that had beeen prepared before in order to gather information in accordance with the objectives of the research . In addition to the interview, the research also used participatory observation.

\section{RESEARCH RESULT}

Every business would need initial capital and the amount will depend on the type of business whether it is small, medium or big business. Food stall business can be categorized in small business with relatively small capital. According to Sumarlin, one of weaknesses of small business is lack of capital, ability and skill in operation and management and no formal form of the company, weak organization and limited marketing. Small business needs development to increase management skill and a development that is not in form of limitless protection since it would make the entrepreneur infantile [3] and [4]

In obtaining the capital, the food stallers often use their own fund. However, some of them use combined capital in establishing their business, which is their own capital and bank loan.

In addition to capital, another thing to note in food stall business management is detailed or undetailed working hour for the employees. Some food stalls applied a detailed working hour system, which is a shift system with total working hour of each manager is nine hours per day. In addition, the employees received 4 days leave per month where the schedule will be adjusted to the condition of the food stall and other employees' leave schedule. It means that the employees cannot have their leave in the same day to avoid shortage of employees in the food stall. Some food 
stalls, however, only apply undetailed working hour where it only applies working hour based on the operational hours of the food stalls.

In managing the business, there is a simple work division system where owner do the cooking job and employees are in charge in preparing the ingredients and serving the consumers indirectly. There is, however, a food stall that applies a clear work division model where managers are divided into two teams. The first team is sales counter team in the front line or service team where one of them is cashier as well as manager of the food stall. The second team is protection in the back part with jobs such as cooking, dish washing and preparing the food ingredients.

Regarding to the work division, it will related to the existence of employees in the food stalls. There are food stalls that do not have employees. On the other hand, there are also food stalls where the manager uses joint management system due to the combined initial capital. The payroll system is also varied among the food stalls. Some food stalls use profit sharing system and others give wage payment based on the educational background or regional minimum wage (Upah Minimum Regional/UMR). Profit sharing system allows employees to receive similar wage each month. If the food stalls attract many customers the wage received will be relatively more. On the contrary, if the food stall is deserted the wage will be lower. In addition, payroll system is based on UMR or educational background. For example, employee with educational background of senior high school (SMA) the UMR is Rp. 500,000.-; thus, this is the amount of the salary received by the employee added with various allowances that depend on the job and division.

\section{STRATEGY TO ATTRACT CONSUMERS}

Strategies implemented by the food stall owners to attract consumers are maintaining the quality of the goods by cooking in small amount and not in big portion or by cooking twice a day, morning and noon. It is avoiding any leftovers to be discarded when the food is not sold out. In maintaining the quality of the ingredients to be processed, the food stall owners will cooperate with the food suppliers. Buying fresh ingredients is another way and soaking them shortly after purchase will make them stay fresh. To maintain the desirable flavor, cooking job is given to staff who skilled in cooking. In addition, the taste of each food stall is maintained by not reducing the spices used in each food. Another strategy to maintain the quality of goods bought by the consumers is by providing the groceries based on the consumers' need.

In 1998, the Council of logistics Management modified its definition of logistics to indicate that logistics is a subset of supply chain management and that the two terms are not synonymoys. Now that this difference has been recognized by the premier logistics professional organization, the challenge is to determine how to successfully implement supply chain management. [6]

In addition to maintaining the quality of the goods, another strategy conducted to attract consumer is the pricing method for the food. The owners of the food stall have freedom to choose methods to be used as long as it does not harm other traders. The first way is the owner adjusts the price of the food based on other food stalls. The second is by calculating the price of ingredients and the cost occurred during the processing of the ingredients plus profit to be obtained. Another way is by having an agreement among the food stall owners about the price. The agreement is given in form of flyer distributed to all the owners. In a case where food stalls have less consumers and the food is not sold, they are allow to reduce the price so they can sell their food in the increasingly tight competition. There is also a strategy used by the food stall owner, especially Tegal food stall in pricing. The pricing for food is arranged by a group of food stall traders centered in Semarang. The organization not only arranges about the menu price but also conducts a monthly social gathering. In the gathering, they usually collect a certain amount of money and draw who gets the money for the month. The money gained from the gathering will be used as additional capital for trader who received it. In this event, a workshop is conducted to discuss about issues faced by the owner regarding price, income or else.

Another strategy for attracting consumers is developing relationship with consumers. The owner of food stall holds a principle that buyers are king. They usually build good relationship with the consumers through chatting, serving with friendly and remembering the loyal consumers. In serving the consumers, the owner competes in fulfilling their food stall facilities. The facilities, for example, free Wi$\mathrm{Fi}$, praying room, hangout room, music, television, lesehan (sitting on the floor) and spacious parking lot.

Moreover, the owners try to beautify their food stall by pasting posters of celebrities that famous among the youth. There are also food stalls that beautify their places with Chinese style or provide buffet style menu so the consumers can serve themselves and choose food according to their preference. Another thing that the owners do to attract consumers is by providing free cold fresh fruits for dine in consumers. All strategies conducted by the owners have the same goals to attract consumers; therefore, more consumers more income.

Related to the maintaining of business sustainability, every food stall owners has their own opinion. Some owners is completely relied their livelihood on the food stall since they consider the income from the business is able to give better life for their family. On the other hand, there are also owners who assume that the business is a side business of their main business. It can be observed on owner who has boarding houses that generate more income in addition to food stall business.

Every owner has different opinion regarding whether they will pass down their business to their children or not. The reason for them who pass their business down to their children is that the business will be able to fulfill their family future needs. There is even a food stall owner who wanted to have their children to go to college so they could help the family business. On the other hand, for owner who does not pass the business down to their children argues that 
the business is a tiring job so it is better for their children to become a civil servant than continuing the business.

\section{CONCLUSION}

Strategies for food stall owners in maintaining their business are by maintaining the quality of the goods, pricing method, and developing relationship with consumers by maintaining the quality of the food through good ingredients, skillful cook, maintaining the taste, gradual cook and discarding the leftovers, prioritizing service, arranging and maintaining the cleanliness, decorating the room, and giving stimulants to consumers. Related to pricing, the methods used by food stall owners are by adjusting with other food stalls, calculating production cost and sales result, making an agreement with other food stall owners and discussing some issues. The sustainability of food stall will be based on the ability of the owner to adapt with the need of consumers and the interest to pass on the business to their children.

\section{REFERENCES}

[1] [1] Marbun, B.N. 1993. Kekuatan dan Kelemahan Usaha Kecil . P.T. Pustaka Binaman Pressindo. Jakarta

[2] [2] Yun Lok Lee and Nerilee Hing. International Journal. Hospitality Management Vol. 14 No.3/4, pp. 293-310, 1995 Copyright @ 1995 Elsevier Science Ltd Printed in Great Britain. All rights reserved

[3] [3] Swasono, Sri Edi. 1975. Pengusaha Kita Dalam Pancaroba Pembangunan. Berita Antropologi. Jakarta

[4] [4] Djohan, Robby. 1984. Peranan Swasta Dalam Perkembangan Ekonomi Indonesia. Penerbit Sinar Harapan. Jakarta

[5] [5] Douglas M. Lambert, Martha C. Cooper and and Janus D. Pagh. Supply Chain Management: Implementation Issues and Research Opportunities. The International Journal of Logistics Management, Volume 9 Number 21998 